\title{
Immunotherapy Applied to Neuropsychiatric Disorders: A New Perspective
}

\section{Pedro Luis Prior*}

Department of Medicine, Federal University of São Paulo, Brazil

Manipulation of the immune system has led to amazing and paradigm -shifting changes in therapeutics and population hazard control measures. It was one of the most important medical discoveries of all time, allowing epidemics control, a great fall in infant, adult and elderly morbidity/mortality and new target development therapies for several hematological and metabolic diseases $[1,2]$.

Several target treatments have already been development in neurobiological models, particularly for neuroinflammatory diseases, such immunosuppressant-resistant myastenia gravis (rituximab) and multiple sclerosis (alemtuzumab). These diseases are,in principle, caused by abnormal immunological function, and these novel treatments act by impeding specific inflammatory action against motor plaque receptors (miastenia gravis) or myelin degradation (multiple sclerosis) [3,4].

There is new evidence to suggest that active and passive immunotherapy may be beneficial not only for infections, but for several neuropsychiatric disorders, including Alzheimer's disease, methamphetamine dependence and nicotine dependence. Though acting by different mechanisms, results are indicative of improvement in general symptoms, preventing relapse of disease, and perhaps even prevention of onset symptoms of said diseases [5-7].

Alzheimer's disease is one of the main diseases where immunotherapy was studied as an alternative in clinical trials. Molecular targets include $\beta$-amyloid plaques which are amassed in brain matter in this clinical setting, and neurofibrillary intracellular tangles composed of tau protein, which are also toxic to neurons [8]. Phase I trials have shown modest results in active immunization with $\beta$-amyloid-like proteins, with lowered plaque burden and improved cognitive symptoms in transgenic mice [9-11]. Comparable results were obtained when passive immunization against epitopes in $\beta$-amyloid plaques was used, and both passive (anti tau antibodies) and active (tau epitopes paired with adenovirus proteins) immunization against tau intracytoplasmatic proteins was performed in mice [1217]. Unfortunately, these alternative treatments have documented side effects such as Th1 response leading to exacerbated glial activation (in $\beta$-amyloid vaccines and anti- $\beta$-amyloid antibodies phase I trials), neuron damage and motor side effects in animal models (in tau protein trials) in animal models [13,17]. However, improved cognitive function was observed in subjects receiving this therapy, especially in those considerate moderately affected by Alzheimer's disease [11-17].

A novel application to active and passive immunotherapy is in the treatment of addictive disorders, such as nicotine, cocaine and methamphetamine.

Cocaine dependence is the most researched drug addiction in this modality of treatment. Clinical experiences are varied from vaccines involving hap ten formulas, anti-idiotypic cocaine antibodies or passive immunization. The results in animal models were positive, with the feasibility for application in human models. Passive immunization in cocaine-dependent rats also showed the possibility of use of catalytic antibodies, with the potential to promote hydrolysis before cocaine molecules reach their intended targets [18-21].

Nicotine hap tens have also been used as molecular targets for nicotine dependent subjects, mainly in active immunization scenarios, with reduction of total nicotine concentration in brain tissue and cerebrospinal fluid, preventing initiation of drug dependence in the pleasure centers of the brain (mesolimbic and mesocortical pathways) in non-addicted models of study [20-24]. The use of hap tens and specific antibodies against other central nervous system stimulants PCP and methamphetamine - has been shown in successful scenarios, lowering drug preference in animal models of non-addiction [25-27].

In conclusion, immunotherapy is a novel area in the treatment of neuropsychiatric disorders, not only because it may hold the key to treating irreversible and degenerative conditions such as Alzheimer's disease, or by provoking hydrolysis of specific addictive molecules such as cocaine, but because it may prevent onset of symptoms of addiction and drug craving. In this way, dependence and addictive behavior could become preventable to the general population when and if exposed to a specific addictive drug, much in the same way a vaccinated population is immune to a specific infectious target.

\section{References}

1. Gilligan AM,Skrepnek GH (2014) Determinants of life expectancy in the Eastern Mediterranean Region. Health Policy Plan .

2. Egli A, Santer D, Barakat K, Z and M, Levin A, et al. (2014) Vaccine adjuvants-understanding molecular mechanisms to improve vaccines. Swiss Med Wkly 144: w13940.

3. Li Y, Arora Y, Levin K (2013) Myasthenia gravis: newer therapies offer sustained improvement. Cleve Clin J Med 80: 711-721.

4. Hersh CM, Cohen JA (2014) Alemtuzumab for the treatment of relapsingremitting multiple sclerosis. Immunotherapy 6: 249-259.

5. Gentry WB, Ruedi-Bettschen D, Owens SM (2009) Development of active and passive human vaccines to treat methamphetamine addiction. Hum Vaccin 5 : 206-213.

6. Lemere CA, Masliah E (2010) Can Alzheimer disease be prevented by amyloidbeta immunotherapy? Nat Rev Neurol 6: 108-119.

7. Carrera MR, Ashley JA, Hoffman TZ, Isomura S, Wirsching P, et al. (2004) Investigations using immunization to attenuate the psychoactive effects of nicotine. Bioorg Med Chem 12: 563-570.

8. Kurz A,Perneczky R (2011) Amyloid clearance as a treatment target against Alzheimer's disease. J Alzheimers Dis 24 Suppl 2: 61-73.

9. Schenk D, Barbour R, Dunn W, Gordon G, Grajeda H, et al. (1999) Immunization with amyloid-beta attenuates Alzheimer-disease-like pathology in the PDAPP mouse. Nature 400: 173-177.

10. Gilman S, Koller M, Black RS, Jenkins L, Griffith SG, et al. (2005) Clinical

*Corresponding authors: Pedro Luis Prior, Department of Medicine, Federal University of São Paulo, Brazil- 11050070, Tel: 55-11-5571-106; E-mail: pedrolsprior@gmail.com

Received August 12, 2014; Accepted September 20, 2014; Published September 20, 2014

Citation: Prior PL (2014) Immunotherapy Applied to Neuropsychiatric Disorders: A New Perspective. Med chem 4: 670-671. doi:10.4172/2161-0444.1000209

Copyright: @ 2014 Prior PL. This is an open-access article distributed under the terms of the Creative Commons Attribution License, which permits unrestricted use, distribution, and reproduction in any medium, provided the original author and source are credited. 
Citation: Prior PL (2014) Immunotherapy Applied to Neuropsychiatric Disorders: A New Perspective. Med chem 4: 670-671. doi:10.4172/21610444.1000209

effects of Abeta immunization (AN1792) in patients with AD in an interrupted trial. Neurology 64: 1553-1562.

11. Holmes C, Boche D, Wilkinson D, Yadegarfar G, Hopkins V, et al. (2008) Longterm effects of Abeta42 immunisation in Alzheimer's disease: follow-up of a randomised, placebo-controlled phase I trial. Lancet 372: 216-223.

12. Roberson ED, Scearce-Levie K, Palop JJ, Yan F, Cheng IH, et al. (2007) Reducing endogenous tau ameliorates amyloid beta-induced deficits in an Alzheimer's disease mouse model. Science 316: 750-754

13. Pfeifer M, Boncristiano S, Bondolfi L, Stalder A, Deller T, et al. (2002) Cerebra hemorrhage after passive anti-Abeta immunotherapy. Science 298: 1379.

14. Wilcock DM, Rojiani A, Rosenthal A, Subbarao S, Freeman MJ, et al. (2004) Passive immunotherapy against Abeta in aged APP-transgenic mice reverses cognitive deficits and depletes parenchymal amyloid deposits in spite of increased vascular amyloid and microhemorrhage. J Neuroinflammation 1: 24.

15. Racke MM, Boone LI, Hepburn DL, Parsadainian M, Bryan MT, et al. (2005) Exacerbation of cerebral amyloid angiopathy-associated microhemorrhage in amyloid precursor protein transgenic mice by immunotherapy is dependent on antibody recognition of deposited forms of amyloid beta. J Neurosci 25: 629-636.

16. Novak M (2010) Tau transgenic rat model and response to tau vaccine. Alzheimers Demen 6: S118.

17. Asuni AA, Boutajangout A, Quartermain D, Sigurdsson EM (2007) Immunotherapy targeting pathological tau conformers in a tangle mouse mode reduces brain pathology with associated functional improvements. J Neurosci 27: $9115-9129$

18. Carrera MRA, Ashley JÁ, Wirsching P, Koob GF, Janda KD (2001) Cocaine vaccines: antibody protection against relapse in a rat model. Proc Natl Acad Sci USA, 98: 1988-1992.
19. Ettinger RH, Ettinger WF, Harless WE (1997) Active immunization with cocaine-protein conjugate attenuates cocaine effects. Pharmacol Biochem Behav 58: 215-220.

20. Johnson MW, Ettinger RH (2000) Active cocaine immunization attenuates the discriminative properties of cocaine. Exp Clin Psychopharmacol 8: 163-167.

21. Schabacker DS, Kirschbaum KS, Segre M (2000) Exploring the feasibility of an anti-idiotypic cocaine vaccine: analysis of the specificity of anticocaine antibodies (Ab1) capable of inducing Ab2beta anti-idiotypic antibodies. Immunology 100: 48-56.

22. Tuncok Y, Hieda Y, Keyler DE, Brown S, Ennifar S, et al. (2001) Inhibition of nicotine-induced seizures in rats by combining vaccination against nicotine with chronic nicotine infusion. Exp Clin Psychopharmacol 9: 228-234.

23. de Villiers SH, Lindblom N, Kalayanov G, Gordon S, Malmerfelt A, et al. (2002) Active immunization against nicotine suppresses nicotine-induced dopamine release in the rat nucleus accumbens shell. Respiration 69: 247-253.

24. Lindblom N, de Villiers SH, Kalayanov G, Gordon S, Johansson AM, et al (2002) Active immunization against nicotine prevents reinstatement of nicotineseeking behavior in rats. Respiration 69: 254-260.

25. Owens SM, Zorbas M, Lattin DL, Gunnell M, Polk M (1988) Antibodies against arylcyclohexylamines and their similarities in binding specificity with the phencyclidine receptor. J Pharmacol Exp Ther 246: 472-478.

26. Owens SM, Mayersohn M (1986) Modulation of phencyclidine (PCP) pharmacokinetics with PCP-specific Fab fragments. NIDA Res Monogr 64:112126.

27. McClurkan MB, Valentine JL, Arnold L, Owens SM (1993) Disposition of a monoclonal anti-phencyclidine Fab fragment of immunoglobulin $G$ in rats. $J$ Pharmacol Exp Ther 266: 1439-1445. 